Using importance-performance analysis to appreciate satisfaction in hotels

Hugh Wilkins

Hugh Wilkins, PhD

Griffith Business School

Griffith University

Queensland 4222

Australia

Email: h.wilkins@griffith.edu.au

Phone: +61 755528011

Fax: +61 755527007

Keywords: Hotels, customer satisfaction, hotel performance, service quality,

sustainability, importance-performance analysis. 


\title{
Using importance-performance analysis to appreciate satisfaction in hotels
}

\author{
Abstract \\ The hotel industry is highly competitive and customer satisfaction is essential \\ for consumer loyalty and business sustainability. This paper reports on two analyses \\ of customer perspectives on hotels. Firstly, the results of an importance - performance \\ analysis are provided. The research identifies a number of areas where hotels over- \\ perform and under-perform. Secondly, this paper provides an evaluation of the effect \\ of gender, age and purpose of trip on the factors customers consider important for \\ hotel selection.
}

The results reported will enable hotels to better manage their product to ensure the sustainability of business performance.

Keywords: Hotels, customer satisfaction, hotel performance, service quality, sustainability, importance-performance analysis. 


\section{Introduction}

In a highly competitive industry, such as the first class and luxury sectors of the hotel industry, it is essential that businesses have a good understanding of the aspects of the business that are important to their customers in order to meet customer expectations with regard to the products and services offered.

The hotel industry is economically important in most countries and provides substantial employment. It is an industry that is highly segmented based on quality, location and style, with higher levels of concentration and competition evident in some sectors, such as the first class and luxury sectors (Go \& Pine, 1995; Littlejohn, 2003; Olsen, 1996). In particular, the higher priced segments are highly competitive with low switching costs (Skogland \& Siguaw, 2004) and little opportunity to develop competitive advantage through differentiation or cost leadership (Bowen \& Shoemaker, 1998; Kandampully \& Suhartanto, 2000).

In highly competitive industries the need to ensure customers are satisfied is essential for business survival due to the demonstrated relationships between customer satisfaction and loyalty (Bowen \& Shoemaker, 1998; Tepeci, 1999). The need to provide customer satisfaction has been identified across many industries (Oh \& Parks, 1997; Wirtz, 2003; Yeung, Ging, \& Ennew, 2002), including the hotel industry (Bowen \& Shoemaker, 1998; Pizam \& Ellis, 1999). Customer satisfaction derives from the quality of the product and service experience in comparison to the previously held expectations (Garbarino \& Johnson, 1999). For an organization to ensure customers are satisfied it is essential for them to know the importance customers place on the individual components of the service experience and how the hotel performs in relation to those components. This information and understanding 
of the customer evaluations is, in a competitive environment, essential in order to achieve and sustain high levels of business performance.

In the hotel industry little research has been undertaken to directly evaluate the differences between customer importance and hotel performance (Yavas \& Babakus, 2003). In previous hotel-based research, the construct of importance has generally been addressed through the criteria used in hotel selection, whilst performance has been measured through service quality and satisfaction research. Although there has been research that has addressed both of these dimensions in hotels, there is limited research that makes comparisons between them.

Importance-performance analysis is a recognized approach for the management of customer satisfaction (Matzler, Sauerwein, \& Heischmidt, 2002). The approach is effective in making comparison between the importance consumers place on an attribute and performance in relation to that attribute (Fallon \& Schofield, 2006; Martilla \& James, 1977; Yavas \& Babakus, 2003). Importance-performance analysis not only provides comparison of the dimensions, but also facilitates a matrix evaluation of the differences between the dimensions, allowing managers to identify areas where they need to revise resource allocation (Matzler et al., 2002). The extension of the technique into the hotel industry provides opportunities for individual hotels to evaluate performance and hotel chains to both evaluate performance and make comparison between properties. In addition, based on a limited sample of Australian hotels, an evaluation of hotel performance in the first class and luxury sectors is provided.

Additionally a number of researchers (e.g. McCleary, Weaver \& Hutchinson, 1993; Callan, 1994; McCleary, Weaver \& Lan, 1994) have previously investigated the effect of age, gender and purpose of trip on hotel selection criteria. This research 
analyses the effect of these variables on the importance of various aspects of service quality.

In this research, the analysis of the aspects of the hotel experience that are affected by age, gender and purpose of trip, and the inclusion of an importanceperformance analysis provides a clear analysis of the hotel consumer. The importance-performance analysis enables an understanding of the dimensions where hotels meet, exceed, or under-perform customer importance, whilst the effects of the other variables will enable hotels to adapt their product more effectively to the market segments they are wishing to attract. These analyses provide a greater understanding of how guests at first class and luxury hotels perceive the service quality delivered by hotels. The analysis will be beneficial to hotel managers and developers in providing a greater understanding of how different cohorts of consumers see the hotel experience. The increased understanding of these effects will enable hotel managers to be more effective in ensuring their properties meet the needs of a diverse range of consumers.

This paper will continue by reviewing the relevant literature before progressing to the research methodology and results. Following the results, a discussion of their impact is provided.

\section{Literature Review}

Despite the established role of importance-performance analysis in evaluating service quality (Fallon \& Schofield, 2006), there has been limited application of the approach within the hotel industry (Yavas \& Babakus, 2003), although there have been examples in tourism (Pike, 2002; Zhang \& Chow, 2004). Importance performance analysis enables the mapping of performance in relation to consumer 
importance enabling identification of areas of over-performance and underperformance (Crompton \& Love, 1995; Fallon \& Schofield, 2006; Huang, Wu, \& Hsu, 2006; Yavas \& Babakus, 2003).

The majority of research in the hotel industry has looked at importance and performance separately and has tended to focus on particular segments, such as business and leisure travelers (Roger J Callan \& Kyndt, 2001; Knutson, 1988; McCleary, Weaver, \& Hutchinson, 1993; McCleary, Weaver, \& Lan, 1994; Weaver \& Oh, 1993), age (Ananth, DeMicco, Moreo, \& Howey, 1992; Wei, Ruys, \& Muller, 1999), gender (McCleary et al., 1994), or hotel standard (Roger J Callan, 1998; Roger J Callan \& Bowman, 2000).

Aspects of the basic hotel product have been ranked as most important across much of the research. In particular, cleanliness has been cited as most important (Roger J Callan \& Bowman, 2000; Knutson, 1988; Lockyer, 2002; Weaver \& McCleary, 1991; Weaver \& Oh, 1993) together with comfortable beds, rooms and good quality towels (Knutson, 1988; Weaver \& McCleary, 1991; Weaver \& Oh, 1993). Other aspects of the hotel that were reported as important included quality staff and service (Knutson, 1988; Lockyer, 2002; Weaver \& McCleary, 1991; Weaver \& Oh, 1993), safety and security (Knutson, 1988; Lockyer, 2002; Weaver \& McCleary, 1991) and added value extras such as free newspapers and cable TV (Weaver \& McCleary, 1991; Weaver \& Oh, 1993).

The literature on hotel performance includes research on service quality and customer satisfaction. A number of factors that influence perceived hotel performance have been identified. Staff performance is seen as an important contributor to hotel performance in several studies (Barsky \& Labagh, 1992; Cadotte \& Turgeon, 1988; Gunderson, Heide, \& Olsson, 1996; Michael D. Hartline \& Jones, 1996; M D 
Hartline, Wooldridge, \& Jones, 2003; McCleary et al., 1994; Saleh \& Ryan, 1991).

Other factors affecting perceived levels of hotel performance included housekeeping standards (Gunderson et al., 1996), location, hotel quality and price (Barsky \& Labagh, 1992).

The literature clearly identifies the individual service encounter as the fundamental component of customer satisfaction (Bitner, Booms, \& Stanfield, 1990). The application of an importance-performance framework will integrate previous research approaches that have separately addressed the issues and develop better understanding of the evaluation of service quality in hotels.

As customer satisfaction is generated by performance either meeting or exceeding expectations (Danaher \& Mattsson, 1994; Oliver, 1980; Spreng, MacKenzie, \& Olshavsky, 1996) it is important for managers to be aware of the cues used by customers in order to maximise satisfaction (Gould-Williams, 1999).

On the basis of the prior research, two research questions were identified. Firstly, it was thought important to provide a direct examination of how hotels perform in relation to areas of customer importance. Previous research has investigated importance and performance separately and has not, therefore, directly compared hotel performance and customer importance across the same range of service quality measures. Consequently, the first research question asks "How effectively do hotels perform in comparison to customer importance”? Secondly, although previous research has independently addressed the effects of gender, age and purpose of trip, no previous research has investigated these variables within one study. Previous research has often combined these aspects, for example, to investigate female business travelers. As a result, the second research question asks “To what extent do the variables of gender, age and purpose of trip affect customer 
importance in hotels”?

\section{Research Methods}

This research adopted a quantitative approach. Quantitative methodology is appropriate for research involving the measurement of aspects of importance and perceptions of performance across a number of dimensions, together with the testing of the relationships between those variables.

Data were collected in relation to perceptions of importance and performance across a number of items identified as contributing to perceived service quality in first class and luxury hotels (Wilkins, Merrilees, \& Herington, 2007). The pool of service quality items were identified from the literature and through qualitative research. Qualitative data were collected through three focus groups and content analyzed using Nvivo software. The qualitative data, together with the literature, was used to develop the range of service quality items. The items were examined by a panel of experts to ensure face validity before being subject to a pilot study. The results of the pilot study informed amendments for inclusion in the final survey instrument.

Respondents were asked to rate importance and performance using a scale from one to ten. Importance and performance measures were not separated as this enabled respondents to consciously evaluate performance in relation to their determinations of importance. It was considered that the separation of performance and importance would lead to confusion and perceived item repetition amongst respondents. The survey items were clustered by heading to allow respondents to focus on a particular aspect of hotel service quality.

The survey was distributed by eight hotels, with there being an equal number of first class (four star) and luxury (five star) hotels. The data were collected from hotels in Queensland, Australia, with both business and leisure properties 
participating. Participating hotels were not related, with some hotels belonging to international brands and others belonging to small groups. All hotels had above 200 rooms. Data were collected from eight hotels as it was thought this would provide an appropriate sample distribution, as well as ensuring participating properties individually collected sufficient data for individual analysis. The survey was a self completed paper-based survey distributed by the selected hotels and returned by respondents through the postal service. There was some variation between hotel distribution approaches, with some hotels leaving surveys in guest rooms for completion and others distributing at the reception desk. Data collection continued over an extended period to ensure each hotel gathered sufficient responses for statistical validity. In order to estimate non-response bias, after data collection was completed, a demographic profile of the respondents was provided to each hotel, with the hotel being asked to verify if the respondent profile reflected the guest profile. In addition, it is often assumed late respondents are similar to non-respondents and these results were compared to earlier responses, with there being no significant difference between them (Armstrong \& Overton, 1977).

The research was focused in the first class and luxury hotel sectors as these sectors are less fragmented and exhibit higher levels of competition (Jones, 2002; Littlejohn, 2003). The survey gained 664 completed usable responses, with an approximate equivalence between first class consumers and luxury consumers. Slightly over half the responses were from leisure consumers (56.3\%), whilst business (32.2\%) and convention (6.4\%) travelers comprised the majority of the rest. Slightly over half the responses were from males (56.3\%) and age was well distributed across the profile of hotel visitors (18-29 years: 14.4\%; 30-44 years: 33.5\%; 45-59 years: $39.6 \%$ and over 60 years: $12.5 \%)$. The data analysis reported is from responses 
across all hotels. Analysis was also undertaken at individual property level to confirm the response pattern was consistent, subject to minor variations, with the results across all hotels.

The survey included sixty three items related to service quality and, in order to identify the naturally occurring dimensions of service quality, all items were placed into an exploratory principal components analysis. This approach is recommended in the literature as a means of identifying actual, rather than perceived, groupings (Rosen \& Surprenant, 1998). An oblique rotation was used as it was anticipated the factors would show high levels of correlation.

The principal component analysis identified seven components with Eigen values greater than one, explaining a combined total of over sixty seven percent of the variance. An examination of the scree plot also indicated that seven components was an appropriate solution. The components were named in relation to the items contained and a confirmatory factor analysis of each of the dimensions supported the solution. After the confirmatory factor analysis, thirty items were retained. Service quality was found to be a higher order factor (Wilkins et al., 2007). The fit indices for the model indicated a good level of fit (Normed $\chi^{2}$ 3.88, AGFI 0.951, RMSEA 0.065, SRMR 0.039).

Two analyses of the hotel consumer were undertaken, an importanceperformance analysis and an analysis of effect of purpose of trip, age and gender on the importance of service quality items.

The first analysis provides the results of a paired samples $\mathrm{T}$ test for the thirty retained items of service quality to identify the performance of the hotels in relation to the importance placed by the consumers on that item. There was a significant difference $(\mathrm{p}<0.01)$ between importance and performance for twenty of the items and 
for two items at $\mathrm{p}<0.05$. The mean values for importance and performance were used, as recommended when there is little consistent difference between mean and median values as was evident in this data (Martilla \& James, 1977).

Secondly, the impact of gender, age and purpose of trip on the importance of a range of service quality dimensions are reported. A multivariate analysis of variance was conducted (MANOVA) to identify if these elements affected the consumer importance of the service quality items.

\section{Results}

The results for the paired samples $\mathrm{T}$ tests for all hotels are shown in Table 1. In Table 1 the items, means for importance and performance, and the significance of the difference in mean values are provided. The importance-performance analysis results were compared between hotels and by gender, purpose of trip and hotel quality. Whilst there were some differences between individual hotels, there was broad consistency, with all hotels showing significant differences between importance and performance on the items identified in Table 1. Where an individual hotel showed difference in importance-performance not reflected by all hotels, this was reduced in significance in the amalgamated data.

\section{INSERT TABLE 1 HERE}

The first dimension was named Stylish Comfort as it reflected the public areas of the hotel. The dimension comprised five retained items with a Cronbach $\alpha$ of 0.883. Three of the retained items showed a significant difference $(\mathrm{p}<0.05)$ between importance and performance. The hotel performance exceeded customer importance 
on two items that reflected those aspects related to the opulence of the hotel and under-performed on an item related to the relaxation of the guests.

The second dimension was named Added Extras as it reflected the value adding offerings of the hotel. The dimension comprised four retained items with a Cronbach $\alpha$ of 0.724 . All of the retained items were significant in their difference between performance and importance. In all of these items the hotel over-performed. These items related to aspects of the hotel experience that were relatively easily managed by the hotel.

The third dimension was named Room Product as it reflected items associated with the room facilities and comfort. The dimension comprised four retained items with a Cronbach $\alpha$ of 0.842 . Of the retained four items, three of them showed a significant difference $(\mathrm{p}<0.05)$ between hotel performance and importance. There is some contrast in the aspects on which hotels over-performed and under-performed. The hotel over-performed on aspects that may be considered as relatively minor, such as branded toiletries and provision of stationery, and under-performed on the provision of quality towels.

The fourth dimension was named Quality Food and Beverage and contained four items, all of which were significant in the difference between hotel performance and customer importance. The dimension had a Cronbach $\alpha$ of 0.835 . The hotel over-performed on all of these items and particularly on the provision of a fine dining restaurant and the range of bars in which to buy drinks.

The fifth dimension was named Quality Staff as it reflected the level of staff performance. The dimension comprised five retained items with a Cronbach $\alpha$ of 0.886. Four items had a significant difference between performance and importance. 
This dimension showed the highest overall levels of importance and the hotels underperformed on all items in this dimension.

The sixth dimension was named Personalization as it reflected the interactions between staff and guests. The dimension comprised four retained items with a Cronbach $\alpha$ of 0.902 . Two of the retained items showed a significant difference between performance and importance. The hotels under-performed on both of these items.

The final dimension was named Speedy Service and reflected the promptness of guest service. The dimension comprised four retained items with a Cronbach $\alpha$ of 0.901. Two of the items showed a significant difference between performance and importance. The hotels over-performed on these items in this dimension.

In importance-performance analysis it is normal practice to evaluate performance through a four quadrant matrix (Oh, 2001). The matrix compares high and moderate (above and below the mean) importance with high and moderate performance. Although some aspects of service quality are categorized as moderate, it should be remembered that all items of service quality were retained through exploratory and confirmatory factor analysis and thus are important to customer satisfaction.

\section{INSERT FIGURE 1 HERE}

In this matrix, the first quadrant (top right) reflects high importance and high performance where both dimensions are above the mean. This quadrant reflects good management with high levels of performance matching the high levels of importance placed on aspects of service quality in this quadrant. The second quadrant (top left) 
reflects high levels of importance, but below average performance. This quadrant is affecting perceived service quality and satisfaction. There is a need to improve performance here to match importance. The third quadrant (bottom left) contains items below the mean for both importance and performance and is seen as a low priority area for management. The final quadrant (bottom right) contains aspects where performance exceeds importance. This implies an over-allocation of resources to the items in this quadrant.

In Table 2 the items that comprise each of the quadrants are identified.

\section{INSERT TABLE 2 HERE}

Although the majority of service quality items fall into either quadrant one or three, both quadrants where there is some correlation between importance and performance, the actual importance and performance scores need examination. In quadrant one, the majority of items fall above the diagonal, indicating importance is greater than performance. As a result, although this quadrant is generally considered to represent maintenance of performance, $(\mathrm{Oh}, 2001)$ a closer evaluation of the items is needed to see if performance improvements may be achieved. In a similar format, the items in the other quadrants also need careful examination rather than adopting a broad classification of satisfactory or unsatisfactory performance. This closer examination identifies a range of problem areas.

As an example, although the items in the dimension Quality Staff all fall within quadrant one, initially indicating continuation of the good work, in practice all items reflect the hotel performing at a lower standard than the level of importance. For all except one of these items the difference is significant $(\mathrm{p}<0.01)$. If an 
importance-performance analysis was undertaken based solely on this dimension, the items would fall into the second quadrant of concentrate here, indicating a need to improve performance.

Individual hotels should undertake an importance - performance evaluation with a close scrutiny on each aspect of their service performance to ensure they are actually delivering what customers want.

The second analysis focused solely on the importance dimension to understand how these aspects of the hotel experience are affected by a range of factors including age, gender and purpose of trip. A MANOVA was undertaken to identify the service quality items where there was a significant effect of these variables on how consumers rated the importance of service quality items. In all cases, the Wilks' Lambda test $(\mathrm{P}<0.01)$ indicated there was a significant effect of these variables on the importance of service quality dimensions. There was a significant impact of age on seven of the thirty items, of gender on sixteen of the items and of purpose of trip on nineteen of the items. A summary of the results are reported in Table 3, with a more detailed discussion being provided later in the paper.

\section{INSERT TABLE 3 HERE}

There was a significant difference in importance between the genders for sixteen of the items. The difference was significant $(\mathrm{p}<0.01)$ for ten of the items and was significant $\left(\mathrm{p}^{<0.05}\right)$ for the remaining six items. For all sixteen items, females had higher levels of importance than did the male travelers. The items that showed most significance $(\mathrm{p}<0.01)$ tended to be associated with the style and image of the hotel, with the quality of both the hotel physical product and the staff service being 
important. An examination of the remaining, non significant, items also showed that females place a higher level of importance on all items with the exception of 'VIP treatment, being the centre of attention'. The MANOVA results for gender are provided in Table 4.

\section{INSERT TABLE 4 HERE}

There was a significant difference in importance arising from the purpose of trip for nineteen of the items. The difference was significant $(\mathrm{p}<0.01)$ for fourteen of the items and was significant $(\mathrm{p}<0.05)$ for the remaining five items. For all nineteen items, leisure travelers had higher levels of importance than did the business travelers. An examination of the remaining items that were not significant also showed, in all cases, leisure travelers identified higher importance for service quality than did business travelers. The MANOVA results for purpose of trip are provided in Table 5.

\section{INSERT TABLE 5 HERE}

Although age had a significant impact on seven service quality items $(\mathrm{p}<0.05)$, there is little initial obvious consistency to the results. As would be expected, there was an age effect on the importance of the hotel providing a gym and recreation facilities, with younger people finding this more important. An examination of the other significant results shows a tendency to polarization with younger people (under 29 years of age) and older people (over 60 years of age) generally both demonstrating higher levels of importance for the remaining items than the intervening age groups. The MANOVA results for age are provided in Table 6. 
INSERT TABLE 6 HERE

\section{Discussion}

In relation to the evaluation of hotel performance in comparison with consumer importance, the results show some tendency for hotels to over-perform on aspects of the hotel experience within the control of the hotel and under-perform on the more complex, or less tangible, aspects of the hotel experience. In parallel, and of particular interest, is that hotels generally over-perform on items of less importance to consumers and under-perform on items of more importance. For the majority of items that may be considered as highly important to consumers, (items with values above the mean for the dimension), the hotels under-performed. This research highlights several important issues for hotel managers and developers. Although there are many specific aspects of the research that are of importance for the industry, there are three particular elements that are noteworthy. First, of the twenty two items showing a significant difference between hotel performance and customer importance, for thirteen of the items the hotel performance exceeds the level of customer importance, whilst for nine of the items, customer importance exceeds hotel performance. For all items ranked highly important (evaluation of above eight on a ten point scale), the hotel under-performed. Second, hotels appear to over-perform on the tangible aspects of performance, particularly those associated with the visible aspects of the hotel, at the expense of the intangible elements that may be harder to quantify, develop and manage. Thirdly, the research shows that the aspects of hotel performance on which the hotel over-performs are associated with items that are rated comparatively low in importance by consumers whilst, in contrast, the aspects of hotel 
performance on which the hotel under-performs are associated with items that are rated comparatively high in importance by consumers.

The three themes depicted above are inter-related and will be discussed together. The research findings reflect an industry that is performing effectively with moderate to high levels of hotel performance and, therefore, it is assumed, moderate to high levels of customer satisfaction. However, the research also indicates a number of areas in which hotels over-perform, and thus waste resources, and a number of areas in which hotels under-perform. A transfer of resources from the overperforming areas to the under-performing areas should result in increased customer satisfaction and, if other research is correct (Oh \& Parks, 1997; Wirtz, 2003; Yeung et al., 2002), would also result in improved business performance. Although the importance - performance analysis grid indicates most aspects of service quality are close to the diagonal across a number of hotels, individual hotels should examine their own importance - performance, as it will differ from the norms.

The contrasts between the aspects of hotel performance that lag and exceed customer importance reflect the differing pressures facing managers in this industry. Hotel managers operate in a complex and demanding environment, with conflicting stakeholder expectations between customer satisfaction and profitability. The broad thrust identified in this research, with some notable exceptions, for example towel quality, is for over-performance on tangible components such as branded toiletries, and the provision of bars and restaurants. Some of these aspects reflect design issues, whilst others are within managerial control. However, in general, they all reflect an escalation in hotel infrastructure that has been evident over recent decades.

In contrast, the areas in which the hotel under-performs relate to two dimensions, first to the aspects of comfort and relaxation, second to the quality of 
staff. Reducing the formality of the lobby area and making it feel more friendly and relaxing may easily address the first of these elements. The second issue relates to staff quality. The research suggests that hotels provide an expected quality of service (Speedy Service; Personalization), although the level of importance in these dimensions was moderate. The imbalance between performance and importance was in the Quality Staff dimension where the level of importance was high and, although hotel performance was also of a high standard, hotels failed to deliver the expected standards. Further investment by hotels in staff training, not in functional performance, but in staff approachability and friendliness, may contribute to a solution to this issue. This problem area is exacerbated by the high levels of staff turnover common in the hotel industry.

Hotels, like most businesses, operate in an environment characterized by scarce resources. The misallocation of resources in relation to the levels of customer importance is effectively to squander those resources. This research enables hotels to weight the allocation of resources to the areas that matter most to consumers and thus to be more effective in resource allocation.

The research has identified some important imbalances between customer importance and hotel performance. The escalation of hotel quality over recent decades may be the cause of elements of this imbalance. As hotels increase in quality they become more formal, and less friendly, whilst at the same time raising customer expectations about their likely hotel experience. Hotels need to identify the fundamental customer expectations if they are going to deliver increased levels of satisfaction.

The second aspect of the research used MANOVA to identify the service quality items whose importance was affected by the variables of purpose of trip, age 
and gender. Although there has been previous research that has investigated all of these aspects, the previous research has tended to investigate the needs of these sectors, rather than the impact of these variables on the importance of aspects of service quality. It is not, therefore, possible to make a comparison between these findings and the previous research. A number of interesting and important findings emerged from this research, particularly in relation to the effect of gender and purpose of trip. Firstly, as reported earlier in this paper, female travelers identify higher levels of importance across all dimensions of service quality where there is a significant difference arising from gender. The largest differences related to room items, including provision of 'large fluffy towels', range of toiletries and the provision of deluxe appliances. Also of major difference were staff issues, including staff attitude at checkout, staff response times and staff remembering requirements. These differences relate to two streams: room comfort and staff performance. In particular, the difference in importance between genders for the provision of quality towels amounted to ten percent of total importance. Although on first impressions these differences are reasonably major, it is quite possible for hotels to meet the expectations of these more demanding consumers by adapting the product and service to meet these needs. At one time hotels often had gender specific floors, albeit for different reasons, and these findings would suggest the re-introduction of this concept may be appropriate, but now targeted at differences in room provision.

The second dimension, that affected nineteen items related to service quality, was the purpose of trip with, for all nineteen items affected, leisure travelers having higher expectations than did business travelers. The most important aspect reflected the hotel quality through the provision of artifacts and paintings, with grandness of the hotel lobby also of importance. The other items where there was a major difference 
arising from purpose of trip all related to the room amenities. It may not be a surprise to find hotel guests, when they pay for their own travel experience, are seeking higher levels of quality. There may also be an effect associated with frequency of travel that affects expectations.

Although there were some items affected by age, there was relatively little consistency, although there was some tendency for younger and older people to have higher expectations.

\section{Conclusion}

The first class and luxury sectors of the hotel industry are recognized as operating in a highly competitive environment. In this environment it is important that businesses maximize customer satisfaction, as satisfied customers are more likely to be loyal, with a positive relationship existing between consumer loyalty and company profitability (Bowen \& Chen, 2001; Buttle, 1996; Hallowell, 1996; Kandampully \& Suhartanto, 2000; Oliver, 1999; Tepeci, 1999). Loyal customers exhibit a number of behavioral facets that contribute to increased profitability including higher levels of purchase, decreased price sensitivity, positive word of mouth and less likelihood of switching brands (Bowen \& Shoemaker, 1998; Buttle, 1996).

Although there has been previous research that has addressed importance, and other research that has addressed performance, there has been very limited research that integrates these aspects within one study. This reflects a fundamental gap in hospitality research, as it is easy to be highly satisfied with something of little interest or importance. This research provides new understandings of the importance performance dimension in hotels. In fact, the research indicates how vitally important 
it is for hotels to monitor the importance - performance matrix in the first instance. Whilst a hotel may believe they are performing to a high standard, without a full understanding of the breakdown of the contrast between importance and performance across all service quality dimensions, it is a fictional belief. As customer satisfaction drives customer loyalty (Oliver, 1999), it should be recognized that if a hotel or any other business does not fully evaluate the importance-performance relationship, then loyalty will remain as an unfilled search ambition.

The effects of gender and purpose of trip on the importance of a range of service quality items are also a critically valuable finding for hotel managers. There is no doubt hotel managers recognize there is a difference in expectations between business and leisure travelers and that gender affects room aspirations. In fact, there was a trend some years ago to adopt female only floors, but driven by a security thrust. This research might suggest the redevelopment of this approach, but driven by a satisfaction thrust. Hotels might also have business and leisure floors. It is not suggested that these would not be attractive to alternative segments, but that they be targeted at a particular segment. Hotels need to adopt a more segmented approach that enables them to attract and satisfy these demanding groups. Alternatively, given the increased importance of a range of service quality aspects for leisure travelers and female travelers, hotels may find the male business traveler a more attractive market segment!

The research will be of practical use to hotel managers in resource allocation and assist them in identifying the aspects of performance that need development. In interpreting this research it should also be recognized that there are a number of limitations. The limitations include the number and location of the hotels. In this research, data were collected in eight hotels located within one Australian state. 
Whilst these hotels and their customers are thought to be reasonably typical of hotels and customers in the first class and luxury sectors in Australia, there may well be differences between countries. There is an opportunity for further research in other countries and cultures to examine how consumers differ, both in the importanceperformance gap and in the effect of gender, age and purpose of trip in their evaluations of the importance of service quality criteria. In addition, the relationship between the importance-performance gap, customer satisfaction and loyalty has not been explored. Customers with either attitudinal or behavioral loyalty might provide different performance evaluations than customers with no loyalty, or new customers. There is an opportunity for future research to test the relationship between customer perceived loyalty and their evaluations of importance and performance. In addition, the link between the importance-performance gap and customer satisfaction has not been tested in this research and there is an opportunity in future research to test this relationship. The use of importance-performance in hotels provides an opportunity for future research in both evaluating how hotel performance in general, across quality or usage dimensions, meets customer expectations and the benchmarking of individual hotel performance to other comparable hotels. 


\section{References}

Ananth, M., DeMicco, F. J., Moreo, P. J., \& Howey, R. M. (1992). Marketplace lodging needs of mature travelers. Cornell Hotel and Restaurant Administration Quarterly, 33(4), 12-24.

Armstrong, J. S., \& Overton, T. S. (1977). Estimating nonresponse bias in mail surveys. Journal of Marketing Research, 14(3), 396-402.

Barsky, J. D., \& Labagh, R. (1992). A strategy for customer satisfaction. Cornell Hotel and Restaurant Administration Quarterly, 33(5), 32-40.

Bitner, M. J., Booms, B. H., \& Stanfield, T. M. (1990). The service encounter:

Diagnosing favorable and unfavorable incidents. Journal of Marketing, 54(1), 71-84.

Bowen, J. T., \& Chen, S.-L. (2001). The relationship between customer loyalty and customer satisfaction. International Journal of Contemporary Hospitality Management, 13(4), 213-217.

Bowen, J. T., \& Shoemaker, S. (1998). Loyalty: A strategic commitment. Cornell Hotel and Restaurant Administration Quarterly, 39(1), 12-25.

Buttle, F. (1996). SERVQUAL: Review, critique, research agenda. European Journal of Marketing, 30(1), 8-35.

Cadotte, E. R., \& Turgeon, N. (1988). Key factors in guest satisfaction. Cornell Hotel and Restaurant Administration Quarterly, 28(4), 45-50.

Callan, R. J. (1998). Attributional analysis of customers' hotel selection criteria by UK grading scheme categories. Journal of Travel Research, 36(3), 20-34.

Callan, R. J., \& Bowman, L. (2000). Selecting a hotel and determining salient quality attributes: A preliminary study of mature British travellers. International Journal of Tourism Research, 2(2), 97-118. 
Callan, R. J., \& Kyndt, G. (2001). Business travellers' perception of service quality: a prefatory study of two European city centre hotels. International Journal of Tourism Research, 3(4), 313-323.

Crompton, J. L., \& Love, L. L. (1995). The predictive validity of alternative approaches to evaluating quality of a festival. Journal of Travel Research, 34(1), 1124.

Danaher, P. J., \& Mattsson, J. (1994). Customer satisfaction during the service delivery process. European Journal of Marketing, 28(5), 5-20.

Fallon, P., \& Schofield, P. (2006). The dynamics of destination attribute importance. Journal of Business Research, 59(6), 709-713.

Garbarino, E., \& Johnson, M. S. (1999). The different roles of satisfaction, trust, and commitment in customer relationships. Journal of Marketing, 63(2), 70-88.

Go, F. M., \& Pine, R. (1995). Globalization strategy in the hotel industry. London: Routledge.

Gould-Williams, J. (1999). The impact of employee performance cues on guest loyalty, perceived value and service quality. Service Industries Journal, 19(3), 97118.

Gunderson, M. G., Heide, M., \& Olsson, U. H. (1996). Hotel guest satisfaction among business travellers: What are the important factors? Cornell Hotel and Restaurant Administration Quarterly, 37(2), 72-79.

Hallowell, R. (1996). The relationships of customer satisfaction, customer loyalty, and profitability: an empirical study. International Journal of Service Industry Management, 7(4), 27-42. 
Hartline, M. D., \& Jones, K. C. (1996). Employee performance cues in a hotel service environment: Influence on perceived service quality, value, and word-of-mouth intentions. Journal of Business Research, 35(3), 207-215.

Hartline, M. D., Wooldridge, B. R., \& Jones, K. C. (2003). Guest perceptions of hotel quality: Determining which employee groups count most. Cornell Hotel and Restaurant Administration Quarterly, 44(1), 43-52.

Huang, Y.-C., Wu, C.-H., \& Hsu, J. C.-J. (2006). Using Importance-Performance Analysis in Evaluating Taiwan Medium and Long Distance National Highway Passenger Transportation Service Quality. Journal of American Academy of Business, 8(2), 98-104.

Jones, P. (Ed.). (2002). Introduction to Hospitality Operations (2nd ed.). London: Continuum.

Kandampully, J., \& Suhartanto, D. (2000). Customer loyalty in the hotel industry: The role of customer satisfaction and image. International Journal of Contemporary Hospitality Management, 12(6), 346-351.

Knutson, B. J. (1988). Frequent travelers: Making them happy and bringing them back. Cornell Hotel and Restaurant Administration Quarterly, 29(1), 83-87. Littlejohn, D. (2003). Hotels. In B. Brotherton (Ed.), The international hospitality industry: Structure, characteristics and issues (pp. 5-29). Oxford: Elsevier Butterworth-Heinemann.

Lockyer, T. (2002). Business guests' accommodation selection: The view from both sides. International Journal of Contemporary Hospitality Management, 14(6), 294300.

Martilla, J. A., \& James, J. C. (1977). Importance-performance analysis. Journal of Marketing, 41(1), 77-79. 
Matzler, K., Sauerwein, E., \& Heischmidt, K. A. (2002). Importance-performance analysis revisted: The role of the factor structure of customer satisfaction. Service Industries Journal, 23(2), 112-129.

McCleary, K. W., Weaver, P. A., \& Hutchinson, J. C. (1993). Hotel selection factors as they relate to business travel situations. Journal of Travel Research, 32(2), 42-48. McCleary, K. W., Weaver, P. A., \& Lan, L. (1994). Gender-based differences in business travellers' lodging preferences. Cornell Hotel and Restaurant Administration Quarterly, 35(2), 51-58.

Oh, H. (2001). Revisiting importance-performance analysis Tourism Management, 22(6), 617-627.

Oh, H., \& Parks, S. C. (1997). Customer satisfaction and service quality: A critical review of the literature and research Implications for the hospitality industry. Hospitality Research Journal, 20(3), 35-64.

Oliver, R. L. (1980). A congitive model of the antecedents and consequences of satisfaction decisions. Journal of Marketing Research, 17(4), 460-470.

Oliver, R. L. (1999). Whence consumer loyalty? Journal of Marketing, 63(4), 33-44.

Olsen, M. (1996). Into the New Millennium. A White Paper on the Global Hospitality Industry (Vol. 1): International Hotel Association.

Pike, S. (2002). The Use of Importance-Performance Analysis to Identify Determinant Short-Break Destination Attributes in New Zealand Pacific Tourism Review, 6(1), 23-33.

Pizam, A., \& Ellis, T. (1999). Customer satisfaction and its measurement in hospitality enterprises. International Journal of Contemporary Hospitality Management, 11(7), 326-339. 
Rosen, D. E., \& Surprenant, C. (1998). Evaluating relationships: Are satisfaction and quality enough? International Journal of Service Industry Management, 9(2), 103125.

Saleh, F., \& Ryan, C. (1991). Analysing service quality in the hospitality industry using SERVQUAL. Service Industries Journal., 11(3), 324-346.

Skogland, I., \& Siguaw, J. A. (2004). Are your satisfied customers loyal? Cornell Hotel and Restaurant Administration Quarterly, 45(3), 221-235.

Spreng, R. A., MacKenzie, S. B., \& Olshavsky, R. W. (1996). A reexamination of the determinants of consumer satisfaction. Journal of Marketing, 60(3), 15-33.

Tepeci, M. (1999). Increasing brand loyalty in the hospitality industry. International Journal of Contemporary Hospitality Management, 11(5), 223-229.

Weaver, P. A., \& McCleary, K. W. (1991, June 24, 1991). Basics bring 'em back. Hotel and Motel Management, 29-38.

Weaver, P. A., \& Oh, H. C. (1993). Do American business travellers have different hotel service requirements? International Journal of Contemporary Hospitality Management, 5(3), 16-21.

Wei, S., Ruys, H., \& Muller, T. E. (1999). A gap analysis of perceptions of hotel attributes by marketing managers and older people in Australia. Journal of Marketing Practice, 5(6), 200-212.

Wilkins, H., Merrilees, B., \& Herington, C. (2007). Towards an understanding of total service quality in hotels. International Journal of Hospitality Management, 26(4), 840-853.

Wirtz, J. (2003). Halo in customer satisfaction measures: The role of purpose of rating, number of attributes and customer involvement. Journal: International Journal of Service Industry Management, 14(1), 96-119. 
Yavas, U., \& Babakus, E. (2003). What Do Guests Look for in a Hotel? A MultiAttribute Approach. Services Marketing Quarterly, 25(2), 1-9.

Yeung, M. C. H., Ging, L. C., \& Ennew, C. T. (2002). Customer satisfaction and profitability: A reappraisal of the nature of the relationship. Journal of Targeting, Measurement and Analysis for Marketing, 11(1), 24-34.

Zhang, H. Q., \& Chow, I. (2004). Application of importance-performance model in tour guides’ performance: evidence from mainland Chinese outbound visitors in Hong Kong Tourism Management 25(1), 81-91. 
Table 1: Paired Sample T Tests - All Hotels

\begin{tabular}{|c|c|c|c|c|c|c|}
\hline Dimension/Item & Importance (I) & Performance (P) & $\mathrm{I}-\mathrm{P}$ & $\begin{array}{l}\text { Std. } \\
\text { Deviation }\end{array}$ & $\mathrm{t}$ & $\begin{array}{l}\text { Sig. (2- } \\
\text { tailed) }\end{array}$ \\
\hline \multicolumn{7}{|l|}{ Stylish Comfort } \\
\hline The hotel lobby is grand & 6.1640 & 6.6589 & -0.4949 & 2.4814 & -5.250 & .000 \\
\hline The ambience of the hotel is relaxing & 8.3809 & 7.7316 & +0.6497 & 1.8389 & 9.296 & .000 \\
\hline The hotel atmosphere is stylish & 7.4968 & 7.3670 & +0.1298 & 0.0804 & 1.614 & .107 \\
\hline The hotel is first class & 7.1493 & 7.1884 & -0.0371 & 0.0819 & -0.453 & 651 \\
\hline The artifacts and paintings added to the image of the hotel & 6.3472 & 6.5738 & -0.2266 & 2.3662 & -2.521 & .012 \\
\hline \multicolumn{7}{|l|}{ Added Extras } \\
\hline Timesaving services such as valet parking & 6.1654 & 6.7906 & -0.6252 & 2.8980 & -5.679 & .000 \\
\hline Floor concierge & 6.8525 & 7.3770 & -0.5245 & 2.4077 & -5.736 & .000 \\
\hline Regular shuttle buses to the airport & 5.5377 & 6.6815 & -1.1438 & 3.0815 & -9.772 & .000 \\
\hline Provision of gym and other recreational facilities & 6.9066 & 7.6865 & -0.7799 & 2.7397 & -7.495 & .000 \\
\hline \multicolumn{7}{|l|}{ Room Quality } \\
\hline Luxurious branded toiletries & 6.6169 & 7.0893 & -0.4724 & 2.2757 & -5.465 & .000 \\
\hline Lots of large fluffy towels & 8.0315 & 7.5626 & +0.4689 & 2.1047 & 5.865 & .000 \\
\hline Range of toiletries available in the bathroom & 7.5006 & 7.6538 & -0.1532 & 2.2108 & -1.824 & .069 \\
\hline Deluxe appliances & 6.1611 & 6.3616 & -0.2005 & 2.4629 & -2.143 & .032 \\
\hline \multicolumn{7}{|l|}{ Quality Food and Beverage } \\
\hline Provision of a sumptuous buffet breakfast & 7.5392 & 7.8731 & -0.3339 & 2.5398 & -3.461 & .001 \\
\hline Good range of bars to buy a drink & 6.4275 & 7.3312 & -0.9037 & 2.5156 & -9.457 & .000 \\
\hline Exquisite food presentation & 7.1589 & 7.5083 & -0.3494 & 2.2673 & -4.057 & .000 \\
\hline Provision of fine dining restaurant & 6.8179 & 7.9000 & -1.0821 & 2.7266 & -10.447 & .000 \\
\hline \multicolumn{7}{|l|}{ Quality Staff } \\
\hline People are nice to you at checkout & 9.1911 & 8.8642 & +0.3269 & 1.4069 & 6.116 & .000 \\
\hline High quality staff who are well trained & 8.9142 & 8.3237 & +0.5905 & 1.6141 & 9.631 & .000 \\
\hline Staff who are quick to respond to requests & 8.8664 & 8.2945 & +0.5719 & 1.7108 & 8.801 & .000 \\
\hline Respectful and polite staff & 9.1915 & 8.7574 & +0.4341 & 1.4203 & 8.045 & .000 \\
\hline Unobtrusive staff & 8.2248 & 8.2126 & +0.0122 & 1.8768 & 0.172 & .864 \\
\hline
\end{tabular}


Personalisation

\begin{tabular}{|c|c|c|c|c|c|c|}
\hline The staff remember your name & 6.5939 & 5.9001 & +0.6938 & 2.7999 & 6.523 & .000 \\
\hline VIP treatment, being the focus of attention & 5.9920 & 6.0747 & -0.0827 & 2.6905 & -0.809 & .419 \\
\hline Staff remembering your requirements & 7.3702 & 6.7570 & +0.6132 & 2.5711 & 6.279 & .000 \\
\hline Being recognized in the lobby & 5.4855 & 5.6130 & -0.1275 & 2.6816 & -1.252 & .211 \\
\hline \multicolumn{7}{|l|}{ Speedy Service } \\
\hline Immediate service & 7.1225 & 7.4445 & -0.3220 & 2.7246 & -3.111 & .002 \\
\hline Every need is anticipated & 6.2418 & 6.6628 & -0.4210 & 2.4300 & -4.561 & .000 \\
\hline Not being kept waiting for more than a minute & 7.3916 & 7.5356 & -0.1440 & 2.7577 & -1.375 & .170 \\
\hline Not having to queue for more than 1 minute & 7.2362 & 7.4284 & -0.1922 & 2.8884 & -1.752 & .080 \\
\hline
\end{tabular}


Figure 1: Importance - Performance Grid

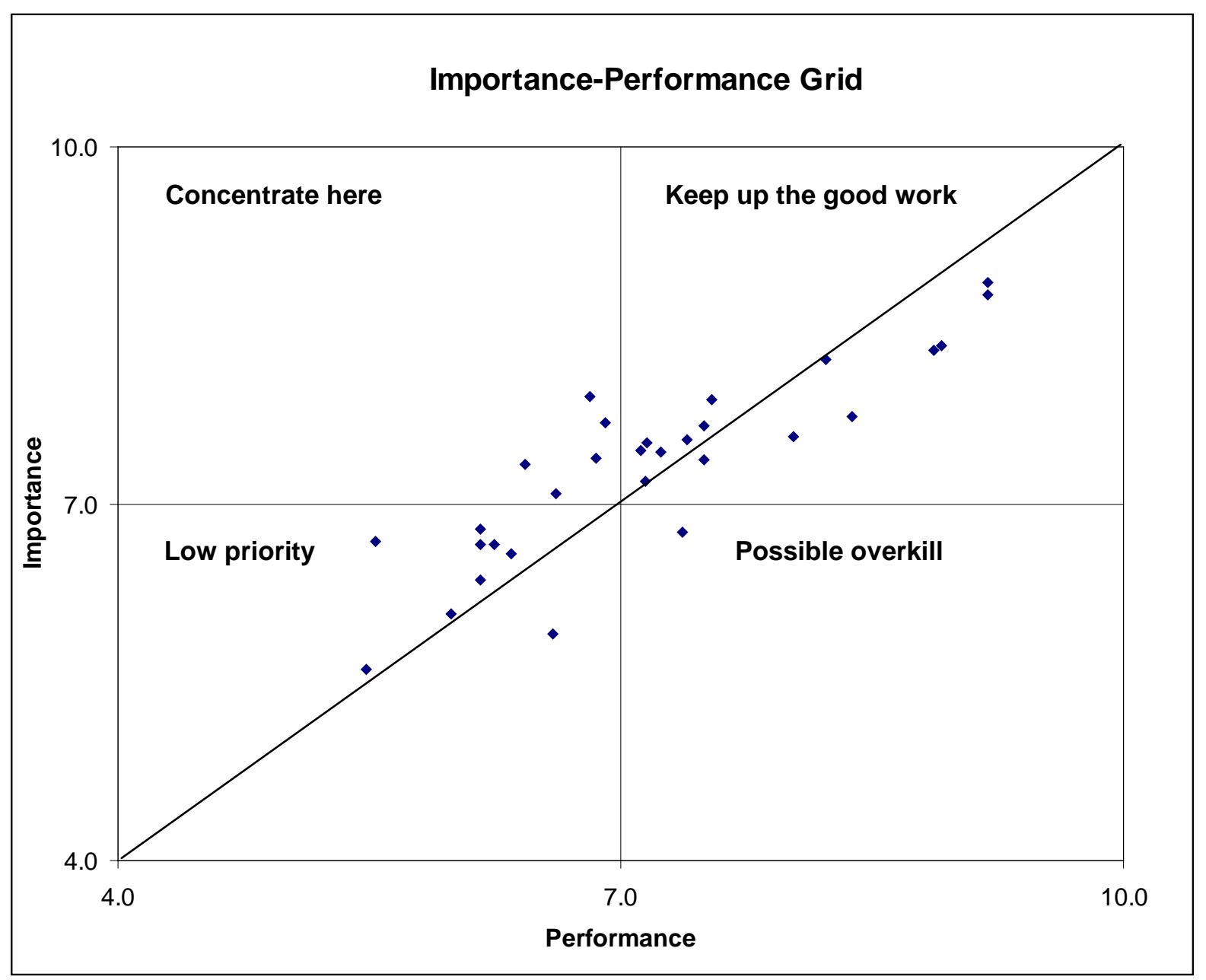


Table 2: Importance - Performance Grid Service Quality Items

\begin{tabular}{|c|c|}
\hline $\begin{array}{l}\text { Quadrant } 1 \\
\text { High Importance and High Performance }\end{array}$ & $\begin{array}{l}\text { People are nice to you at checkout } \\
\text { Respectful and polite staff } \\
\text { High quality staff who are well trained } \\
\text { Staff who are quick to respond to requests } \\
\text { The ambience of the hotel is relaxing } \\
\text { Unobtrusive staff } \\
\text { Lots of large fluffy towels } \\
\text { Provision of a sumptuous buffet breakfast } \\
\text { Range of toiletries available in the bathroom } \\
\text { The hotel atmosphere is stylish } \\
\text { Not being kept waiting for more than a minute } \\
\text { Not having to queue for more than } 1 \text { minute } \\
\text { Exquisite food presentation } \\
\text { Immediate service } \\
\text { The hotel is first class }\end{array}$ \\
\hline $\begin{array}{l}\text { Quadrant } 11 \\
\text { High Importance and Low to Moderate } \\
\text { Performance }\end{array}$ & Staff remembering your requirements \\
\hline $\begin{array}{l}\text { Quadrant } 111 \\
\text { Low to Moderate Importance and Low to } \\
\text { Moderate Performance }\end{array}$ & $\begin{array}{l}\text { Regular shuttle buses to the airport } \\
\text { Timesaving services such as valet parking } \\
\text { The hotel lobby is grand } \\
\text { Every need is anticipated } \\
\text { The artifacts and paintings added to the image of the } \\
\text { hotel } \\
\text { Deluxe appliances } \\
\text { VIP treatment, being the focus of attention } \\
\text { The staff remember your name } \\
\text { Being recognized in the lobby }\end{array}$ \\
\hline $\begin{array}{l}\text { Quadrant 1V } \\
\text { Low to Moderate Importance and High } \\
\text { Performance }\end{array}$ & $\begin{array}{l}\text { Provision of fine dining restaurant } \\
\text { Provision of gym and other recreational facilities } \\
\text { Floor concierge } \\
\text { Luxurious branded toiletries } \\
\text { Good range of bars to buy a drink }\end{array}$ \\
\hline
\end{tabular}


Table 3: Summary of MANOVA Results

\begin{tabular}{|c|c|c|c|}
\hline Dimension/Item & Age & Gender & Purpose of Trip \\
\hline \multicolumn{4}{|l|}{ Stylish Comfort } \\
\hline The hotel lobby is grand & $*$ & & $* *$ \\
\hline \multicolumn{4}{|l|}{ The ambience of the hotel is relaxing } \\
\hline The hotel atmosphere is stylish & & $* *$ & $* *$ \\
\hline The hotel is first class & $*$ & $*$ & $* *$ \\
\hline $\begin{array}{l}\text { The artifacts and paintings added to the image of } \\
\text { the hotel } \\
\text { Added Extras }\end{array}$ & & $* *$ & $* *$ \\
\hline Timesaving services such as valet parking & & & $*$ \\
\hline Floor concierge & & & $*$ \\
\hline Regular shuttle buses to the airport & & & $* *$ \\
\hline Provision of gym and other recreational facilities & $* *$ & $*$ & \\
\hline \multicolumn{4}{|l|}{ Room Quality } \\
\hline Luxurious branded toiletries & & $*$ & $* *$ \\
\hline Lots of large fluffy towels & & $* *$ & $* *$ \\
\hline Range of toiletries available in the bathroom & & $* *$ & ** \\
\hline Deluxe appliances & * & $* *$ & $* *$ \\
\hline \multicolumn{4}{|l|}{ Quality Food and Beverage } \\
\hline \multicolumn{4}{|l|}{ Provision of a sumptuous buffet breakfast } \\
\hline Good range of bars to buy a drink & $* *$ & & $* *$ \\
\hline Exquisite food presentation & & * & $*$ \\
\hline Provision of fine dining restaurant & & & $* *$ \\
\hline \multicolumn{4}{|l|}{ Quality Staff } \\
\hline People are nice to you at checkout & & $* *$ & $* *$ \\
\hline High quality staff who are well trained & & $* *$ & $* *$ \\
\hline Staff who are quick to respond to requests & & ** & \\
\hline Respectful and polite staff & & $*$ & $*$ \\
\hline Unobtrusive staff & & $* *$ & $*$ \\
\hline \multicolumn{4}{|l|}{ Personalization } \\
\hline \multicolumn{4}{|l|}{ The staff remember your name } \\
\hline \multicolumn{4}{|l|}{ VIP treatment, being the focus of attention } \\
\hline Staff remembering your requirements & & $* *$ & \\
\hline \multicolumn{4}{|l|}{ Being recognized in the lobby } \\
\hline \multicolumn{4}{|l|}{ Speedy Service } \\
\hline \multicolumn{4}{|l|}{ Not being kept waiting for more than a minute } \\
\hline Immediate service & $*$ & & \\
\hline Every need is anticipated & $*$ & $*$ & $* *$ \\
\hline
\end{tabular}

\section{* Significant $\mathbf{p}<.05 \quad * *$ Significant $\mathbf{p}<.01$}


Table 4: MANOVA Results - Gender

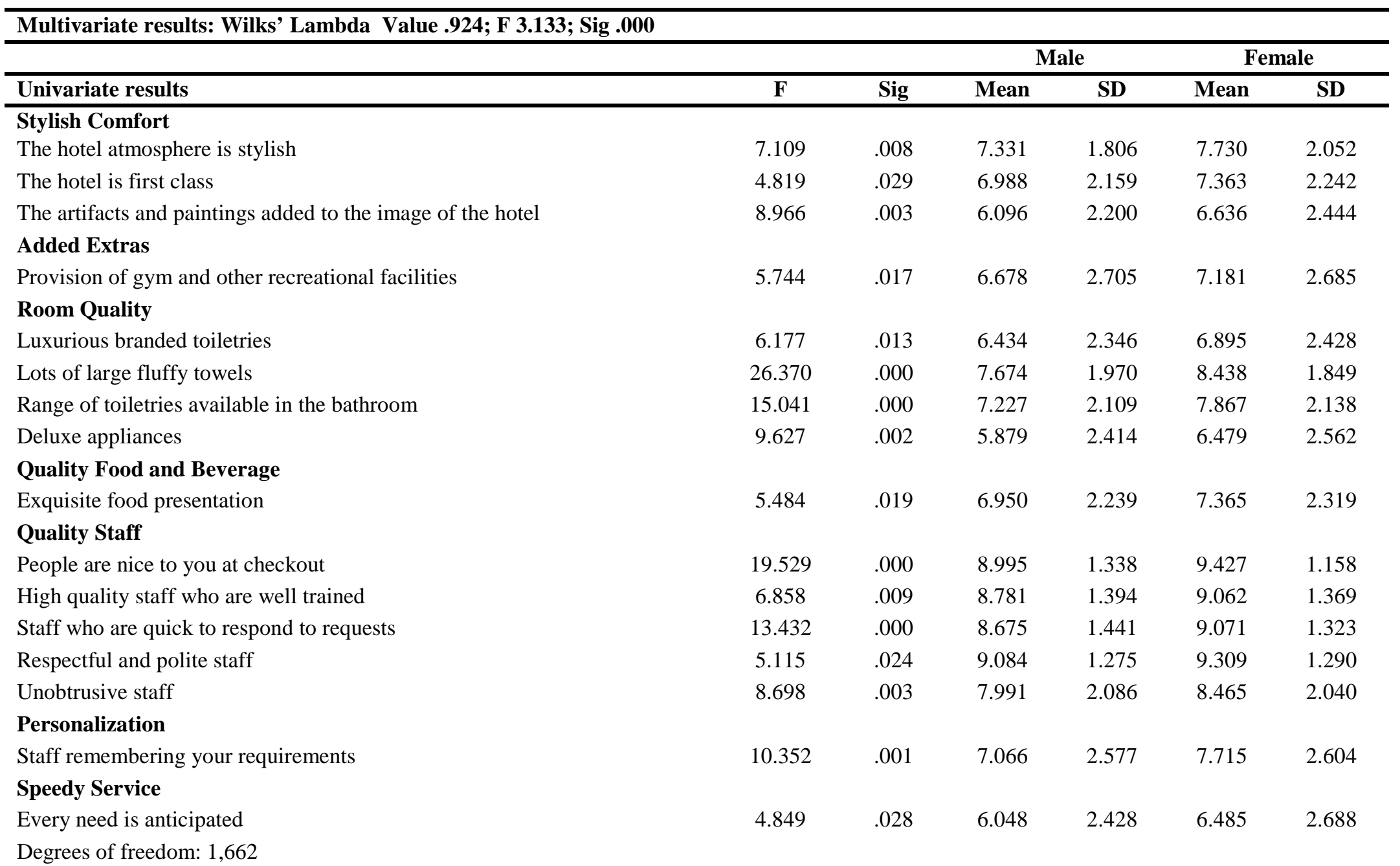


Table 5: MANOVA Results - Purpose of Trip

\begin{tabular}{|c|c|c|c|c|c|c|}
\hline \multicolumn{7}{|c|}{ Multivariate results: Wilks' Lambda Value .847; F 1.949; Sig .000 } \\
\hline \multirow[b]{2}{*}{ Univariate results } & \multirow[b]{2}{*}{$\mathbf{F}$} & \multirow[b]{2}{*}{ Sig } & \multicolumn{2}{|c|}{ Business } & \multicolumn{2}{|c|}{ Leisure } \\
\hline & & & Mean & SD & Mean & SD \\
\hline \multicolumn{7}{|l|}{ Stylish Comfort } \\
\hline The hotel lobby is grand & 10.446 & .000 & 5.517 & 2.279 & 6.567 & 2.302 \\
\hline The hotel atmosphere is stylish & 5.014 & .002 & 7.104 & 1.915 & 7.732 & 1.920 \\
\hline The hotel is first class & 11.597 & .000 & 6.469 & 2.215 & 7.546 & 2.154 \\
\hline The artifacts and paintings added to the image of the hotel & 5.558 & .001 & 5.865 & 2.379 & 6.601 & 2.345 \\
\hline \multicolumn{7}{|l|}{ Added Extras } \\
\hline Timesaving services such as valet parking & 2.846 & .037 & 5.783 & 2.944 & 6.314 & 2.828 \\
\hline Floor concierge & 3.740 & .011 & 6.429 & 2.736 & 7.085 & 2.518 \\
\hline Regular shuttle buses to the airport & 3.938 & .008 & 4.962 & 2.887 & 5.798 & 3.214 \\
\hline \multicolumn{7}{|l|}{ Room Quality } \\
\hline Luxurious branded toiletries & 11.409 & .000 & 5.894 & 2.459 & 7.022 & 2.270 \\
\hline Lots of large fluffy towels & 11.223 & .000 & 7.446 & 2.043 & 8.378 & 1.771 \\
\hline Range of toiletries available in the bathroom & 6.197 & .000 & 7.004 & 2.146 & 7.756 & 2.129 \\
\hline Deluxe appliances & 13.367 & .000 & 5.299 & 2.397 & 6.552 & 2.467 \\
\hline \multicolumn{7}{|l|}{ Quality Food and Beverage } \\
\hline Good range of bars to buy a drink & 6.090 & .000 & 5.823 & 2.572 & 6.658 & 2.663 \\
\hline Exquisite food presentation & 2.729 & .043 & 6.804 & 2.290 & 7.348 & 2.322 \\
\hline Provision of fine dining restaurant & 4.522 & .004 & 6.274 & 2.644 & 7.073 & 2.689 \\
\hline \multicolumn{7}{|l|}{ Quality Staff } \\
\hline People are nice to you at checkout & 4.777 & .003 & 9.033 & 1.379 & 9.320 & 1.189 \\
\hline High quality staff who are well trained & 3.991 & .008 & 8.719 & 1.524 & 9.078 & 1.255 \\
\hline Respectful and polite staff & 3.454 & .016 & 9.029 & 1.407 & 9.320 & 1.187 \\
\hline Unobtrusive staff & 2.814 & .039 & 7.901 & 2.086 & 8.400 & 2.058 \\
\hline \multicolumn{7}{|l|}{ Speedy Service } \\
\hline Every need is anticipated & 4.109 & .007 & 5.771 & 2.438 & 6.520 & 2.621 \\
\hline
\end{tabular}


Table 6: MANOVA Results - Age

\begin{tabular}{|c|c|c|c|c|c|c|c|c|c|c|}
\hline \multicolumn{11}{|c|}{ Multivariate results: Wilks' Lambda Value .853; F 5.224; Sig .000 } \\
\hline \multirow[b]{2}{*}{ Univariate results } & \multirow[b]{2}{*}{$\mathbf{F}$} & \multirow[b]{2}{*}{ Sig } & \multicolumn{2}{|c|}{ 18-29 } & \multicolumn{2}{|c|}{$30-44$} & \multicolumn{2}{|c|}{ 45-59 } & \multicolumn{2}{|c|}{$60+$} \\
\hline & & & Mean & SD & Mean & SD & Mean & SD & Mean & SD \\
\hline \multicolumn{11}{|l|}{ Stylish Comfort } \\
\hline The hotel lobby is grand & 2.949 & .032 & 6.643 & 2.212 & 6.016 & 2.373 & 6.009 & 2.339 & 6.572 & 2.331 \\
\hline The hotel is first class & 3.704 & .012 & 7.059 & 2.210 & 6.823 & 2.310 & 7.336 & 2.094 & 7.618 & 2.089 \\
\hline \multicolumn{11}{|l|}{ Added Extras } \\
\hline Provision of gym and other recreational facilities & 15.988 & .000 & 7.968 & 2.199 & 7.270 & 2.481 & 6.680 & 2.768 & 5.478 & 2.891 \\
\hline \multicolumn{11}{|l|}{ Room Quality } \\
\hline Deluxe appliances & 3.401 & .017 & 6.711 & 2.606 & 5.835 & 2.480 & 6.111 & 2.435 & 6.469 & 2.453 \\
\hline \multicolumn{11}{|l|}{ Quality Food and Beverage } \\
\hline Good range of bars to buy a drink & 4.094 & .007 & 7.245 & 2.418 & 6.365 & 2.612 & 6.180 & 2.680 & 6.437 & 2.574 \\
\hline \multicolumn{11}{|l|}{ Speedy Service } \\
\hline Immediate service & 3.564 & .014 & 7.633 & 2.417 & 7.312 & 2.403 & 6.798 & 2.314 & 7.074 & 2.733 \\
\hline Every need is anticipated & 3.608 & .013 & 6.811 & 2.562 & 6.424 & 2.492 & 5.905 & 2.523 & 6.258 & 2.708 \\
\hline
\end{tabular}

